\title{
Assessment of adherence to the dietary recommendations concerning the amount of carbohydrates intake in type 1 diabetic patients treated with continuous subcutaneous insulin infusion during pregnancy and 8 weeks after the delivery
}

\section{ABSTRACT}

Introduction. Pregnancy in type 1 diabetic women is a special period requiring intensified care performed by the multidisciplinary therapeutic team. Maintaining the recommended rigorous glycemic control is crucial condition for the correct development of the foetus, and the mother's health. The menu of pregnant diabetic patients should provide them with all essential diet nutrients. Among them, carbohydrates affect blood glucose level the most strongly. Not only their amount, but also type and distribution are important. Material and methods. The study group consisted of 32 pregnant women with type 1 diabetes. All patients were treated with intensive insulin therapy with the use of continuous subcutaneous insulin infusion (CSII). In all cases we evaluated: glycated hemoglobin $\left(\mathrm{HbA}_{1 \mathrm{c}}\right)$, body weight, daily intake of carbohydrates, the adher-

Address for correspondence:

mgr Sylwia Karbowska

Katedra i Klinika Chorób Wewnętrznych i Diabetologii

Uniwersytetu Medycznego im. Karola Marcinkowskiego w Poznaniu Szpital Miejski im. Fr. Raszei

ul. A. Mickiewicza 2, 60-834 Poznań

Phone/fax: +48 (61) 2245270

e-mail: skarbowska@gmail.com

Translation: GROY Translations

Clinical Diabetology 2016, 5, 2, 49-56

DOI: $10.5603 /$ DK.2016.0009

Received: 02.11.2015

Accepted: 25.01.2016 ence to the dietary recommendations concerning the amount of carbohydrates intake (per day) - at the time of diagnosis of pregnancy, in $24^{\text {th }}$ and $36^{\text {th }}$ week of pregnancy as well as 8 weeks after childbirth. The recommended carbohydrate intake was calculated individually for each patient and accounted for $40-45 \%$ of the daily energy demand. The consumption of the recommended amount of carbohydrates was assessed as $100 \%$ adherence. The information about carbohydrate intake in each trimester and after childbirth, was obtained from the computer program used to read data from the personal insulin pump and from patients self-monitoring diaries.

Results. Recommended daily carbohydrate intake for the entire study group was approx. $205.6 \pm 34.2 \mathrm{~g}$ of carbohydrates. The adherence to the recommendations assessed in $1^{\text {st }}, 2^{\text {nd }}$ and $3^{\text {rd }}$ trimester and 8 weeks after childbirth was: $82.8 \pm 28.3 \%, 91.1 \pm 29.7 \%, 97.3 \pm$ $\pm 34.8 \%, 69.9 \pm 32.6 \%$, respectively $(p<0.00001)$. After birth, breastfeeding subjects consumed $60.2 \pm$ $\pm 24.5 \%$ of the recommended carbohydrate intake, while for non-breastfeeding subjects it was $91.4 \pm$ $\pm 38.9 \%(p=0.01)$. Subjects with normal body weight before pregnancy followed the recommendation in the $1^{\text {st }}, 2^{\text {nd }}$ and $3^{\text {rd }}$ trimester and 8 weeks after birth in $73.4 \pm 19.9 \%, 83.4 \pm 23.7 \%, 91.2 \pm 30.2 \%, 63.4 \pm$ $\pm 25.3 \%$, respectively, while overweight subjects in $111.0 \pm 32.1 \%, 114.5 \pm 34.9 \%, 115.8 \pm 42.9 \%, 89.8 \pm$ $\pm 44.7 \%$, respectively. 
Conclusion. Pregnant type 1 diabetic women with normal body weight before pregnancy consumed less carbohydrates than recommended. Compliance concerning dietary recommendations significantly differed in particular trimesters and 8 weeks after birth. We observed a statistically significant decrease in the adherence to the recommendation after pregnancy. Breastfeeding subjects consumed less carbohydrates than non-breastfeeding. Overweight subjects consumed more carbohydrates than recommended. (Clin Diabet 2016, 5, 2: 49-56)

Key words: type 1 diabetes, pregnancy, diet

\section{Introduction}

Pregnancy in type 1 diabetic women is a special period requiring intensified care performed by the multidisciplinary therapeutic team. Condition, when women with diabetes, get pregnant (regardless of diabetes type) is defined as pregestational diabetes mellitus (PGDM) [1]. Maintaining the recommended glycemic control is crucial condition for the correct development of the foetus, and the mother's health [2]. The Diabetes Poland advice pregnant women to maintain their glycemic values in self-control both fasting and before-meals in the range of $60-90 \mathrm{mg} / \mathrm{dl}$, and 1 hour after meal below $120 \mathrm{mg} / \mathrm{dl}$, while in the night above $60 \mathrm{mg} / \mathrm{dl}$. It is also recommended to monitor the value of $\mathrm{HbA}_{1 \mathrm{c}}$ in women with PGDM every 6 weeks to obtain a value below $6.0 \%[1,3]$.

A fundamental element of PGDM therapy is an intensive insulin therapy which ensures maintaining glycemia in the reference range, preventing ketonuria as well as proper dietary treatment.

The menu of pregnant diabetic patients should provide them with all essential diet nutrients. The need to modify diet is a result of increasing energy demand of a woman's body, mainly demand for nutrients, vitamins and minerals related to foetus growth and development [2]. Energy demand in woman with PGDM is determined based on her initial body weight, height, age and physical activity. In case of normal body weight, it is recommended to intake of approx. $35 \mathrm{kcal}$ per kg of normal body weight, which gives approx. 1500-2400 kcal per day [1]. In case of obesity and overweight it is recommended diet restrictions tailored to the individual needs of the body. It was shown that in obese women, reduction of calories intake to $1800 \mathrm{kcal}$ per day decreases glucose blood level and decreases the risk of macrosomia in new born without increasing a risk of ketonuria [4]. A good and practical indicator in assessing energy needs is increase of a pregnant woman's
Table 1. Recommended daily energy intake according to guidelines of the Polish Gynaecological Society on management of diabetic women

\begin{tabular}{lcc}
\hline $\begin{array}{l}\text { BMI of pregnant Recommended body } \\
\text { woman } \\
{\left[\mathrm{kg} / \mathrm{m}^{2}\right]}\end{array}$ & $\begin{array}{c}\text { Recommended } \\
\text { weight increase } \\
\text { during pregnancy }[\mathrm{kg}]\end{array}$ & $\begin{array}{c}\text { calorie intake per } \\
\text { kg of body weight }\end{array}$ \\
\hline$<19.8$ & $12.5-18.0$ & $35-40$ \\
$19.8-26.0$ & $11.4-15.9$ & $30-32$ \\
$26.1-29.0$ & $6.5-11.4$ & $25-30$ \\
$>29.0$ & $<7.0$ & $24-25$ \\
\hline
\end{tabular}

$\mathrm{BMI}$ - body mass index

body weight. Well balanced diet in energy intake and quality products should ensure correct body weight increase during the pregnancy. In obese women (BMI above $30 \mathrm{~kg} / \mathrm{m}^{2}$ ) it is recommend to normalize body weight and its maximum increase during pregnancy should not exceed $7 \mathrm{~kg}$. While in underweight patients (BMI below $19.8 \mathrm{~kg} / \mathrm{m}^{2}$ ) increase even by up to $18 \mathrm{~kg}$ is allowable (Table 1) $[3,5]$.

According to the recommendations of the Polish Gynaecological Society daily nutritional ration in type 1 diabetic patients during pregnancy should be divided into 3 main meals and 3 snacks which shall be composed in the following manner: $40-45 \%$ of carbohydrates (predominantly complex ones), $30 \%$ of protein $(1.3 \mathrm{~g} / \mathrm{kg}$ of body weight), $20-30 \%$ of fats (predominantly unsaturated ones) [3]. The American Diabetes Association draws attention to the individual composition of macronutrients in the diet of a pregnant woman, suggesting the following composition: $40-45 \%$ carbohydrates, $20-25 \%$ protein and $30-35 \%$ fats [6].

Among them, carbohydrates affect blood glucose level the most strongly. Not only their amount, but also type and distribution are important. In clinical practice, benefits of applying diet containing carbohydrate compositions of low glycemic index, i.e. carbohydrates from whole grain cereal products, legumes, fresh, unprocessed vegetables and starchy foods are observed [7]. Carbohydrate content shall depend on initial body weight as well as on observed in individual trimesters body weight increase, physical activity, insulin therapy model and obtained daily glycemic profile. In order to obtain very good metabolic control in pregnant women, a low-carbohydrate diet is recommended, with carbohydrate content equal to $40-45 \%$ of daily energy demand. Due to the risk of ketonuria, minimum daily intake of carbohydrates cannot be below $175 \mathrm{~g}$ [7-9]. Patients with high insulin resistance and obesity may require reduction of carbohydrate dietary content down to $33-35 \%$ [4]. In order to estimate carbohydrate intake 
per day in a patient treated with functional intensified insulin therapy (FIT) using pen or continuous subcutaneous insulin infusion (CSII) a term Carbohydrate exchange (CE) is used. 1 Carbohydrate exchange is defined as 10 grams of assimilable carbohydrates in a particular ration of given product. The education of type 1 diabetic pregnant patient includes, apart from dietary recommendations and diet plan, training in estimating carbohydrate intake by weighing food products, and using prepared Carbohydrate exchange tables as well as data available on the food packaging [5]. It seems that despite high motivation of type 1 diabetic pregnant women to improve their glycemia, following the recommendations can be difficult.

The aim of this article is to assess the adherence to the dietary recommendations in terms of carbohydrate intake in type 1 diabetic subjects treated with CSII.

\section{Material and methods}

The study group consisted of pregnant women with type 1 diabetes treated in the Diabetes Clinic at Department of Internal Medicine and Diabetology of the Poznan University of Medical Sciences. All the patients since the diagnosis of diabetes were treated by means of functional intensified insulin therapy and educated multiple times in calculations of carbohydrate exchanges. Patients treated with CSII were enrolled.

In all cases we evaluated: glycated hemoglobin $\left(\mathrm{HbA}_{1 \mathrm{c}}\right)$, body weight, daily intake of carbohydrates, the adherence to the dietary recommendations concerning the amount of carbohydrates intake (per day) - at the time of diagnosis of pregnancy, in $24^{\text {th }}$ and $36^{\text {th }}$ week of pregnancy as well as 8 weeks after the childbirth.

At the moment of pregnancy diagnosis, each female patient was trained by a qualified dietician in healthy eating during pregnancy, recommended daily carbohydrates intake and their proper distribution between individual meals. Moreover, the patients were reeducated in correct calculations of CE using CE tables, food labels and available apps for CE calculations.

The recommended carbohydrate intake was calculated individually for each patient. The consumption of the recommended amount of carbohydrates was assessed as $100 \%$ treatment adherence. The calculated individually carbohydrate intake accounted for $40-45 \%$ of the guideline daily amount (GDA). The content of carbohydrates at level of $40 \%$ GDA was calculated for patients with obesity, while carbohydrate intake of $45 \%$ GDA was recommended for patients with normal body weight. Daily energy requirements for each patient was calculated according to the guidelines of the Polish Gynaecological Society on management of diabetic women and Diabetes Poland according to the correct body weight of the patients (Table 1).

After birth, GDA for each patient was calculated using Harris-Benedict equation for basic metabolic rate including age, height, body weight and physical activity. In case of breast-feeding GDA was increased by 450 kcal according to the recommendations of the American Academy of Pediatrics [10]. This patient group was taught about dietary recommendations applicable during breast-feeding according to the guidelines prepared by the Expert Group for dietary recommendations for lactating women.

The information about carbohydrate intake in each trimester and after childbirth, was obtained from the computer program used to read data from the personal insulin pump and from patients' self-controling diaries.

The statistical evaluation of the results was performed using Statistica PL, ver. 10.0. software. The comparison of variables with normal distribution was performed using Kolmogorov-Smirnov test (K-S test) with Lilliefors correction. For numerical variables, the difference between groups were analysed using Mann-Whitney $U$ test and for categorical variables, the analysis was based on chi-square test. The results were presented by numbers and percentages expressed as average value \pm standard deviation (SD). The assumed significance level was $p<0.05$.

\section{Results}

The study group consisted of 32 pregnant women with type 1 diabetes in age of $29.7 \pm 2.7$ years. The average body weight of subjects at diagnosis of the pregnancy was $62.7 \pm 9.7 \mathrm{~kg}$, while average body mass index (BMI) was $22.5 \pm 3 \mathrm{~kg} / \mathrm{m}^{2}$. The normal body weight, i.e. BMI value in the range 18.5 $-24.9 \mathrm{~kg} / \mathrm{m}^{2}$ was found in 24 patients, which accounted for $75 \%$ of the study group, while 8 patients (25\%) were obese (BMI $25-29.9 \mathrm{~kg} / \mathrm{m}^{2}$ ). Study group characteristics is presented in Table 2 .

Average $\mathrm{HbA}_{1 \mathrm{c}}$ values in individual trimesters are presented in Table 3. Average $\mathrm{HbA}_{1 \mathrm{c}}$ values 8 weeks

Table 2. Characteristics of studied group of pregnant women with pregestational diabetes mellitus (PGDM) at the moment of diagnosis of pregnancy

\begin{tabular}{lc}
\hline Selected parameters & Average value + SD \\
\hline Age [years] & $29.7 \pm 2.7$ \\
Body weight $[\mathrm{kg}]$ & $62.7 \pm 9.7$ \\
Height $[\mathrm{cm}]$ & $166.9 \pm 6.7$ \\
BMI $\left[\mathrm{kg} / \mathrm{m}^{2}\right]$ & $22.5 \pm 3$ \\
\hline
\end{tabular}

$\mathrm{BMI}$ - body mass index; SD — standard deviation 
Table 3. Comparison of intake of carbohydrates, observing adherence to the recommendation, glycated hemoglobin $\left(\mathrm{HbA}_{1 \mathrm{c}}\right)$, daily insulin requirement per day in studied group

\begin{tabular}{lccccc}
\hline & $1^{\text {st }}$ trimester & $\mathbf{2}^{\text {nd }}$ trimester & $3^{\text {rd }}$ trimester & $\mathbf{8}$ weeks after the delivery & $\mathbf{p}$ \\
\hline Carbohydrates intake/day [g] & $164.7 \pm 43.2$ & $183.4 \pm 52.7$ & $196.6 \pm 66.7$ & $156.6 \pm 58.9$ & 0.00062 \\
Adherence to the recommendations (\%) & $82.8 \pm 28.3$ & $91.1 \pm 29.7$ & $97.3 \pm 34.8$ & $69.9 \pm 32.6$ & $<0.00001$ \\
$\mathrm{HbA}_{1 \mathrm{c}}(\%)$ & $6.5 \pm 1.0$ & $5.5 \pm 0.5$ & $5.8 \pm 0.6$ & $6.1 \pm 0.9$ & $<0.00001$ \\
Insulin/day [u] & $35.8 \pm 8.6$ & $44.3 \pm 11.0$ & $65.2 \pm 19.8$ & $33.1 \pm 10.5$ & $<0.00001$ \\
\hline
\end{tabular}

Table 4. Comparison of glycated hemoglobin $\left(\mathrm{HbA}_{1 \mathrm{c}}\right)$, adherence to the recommendations and intake of carbohydrates among women breastfeeding and non-breastfeeding postpartum

\begin{tabular}{lccc}
\hline & Breastfeeding $(\mathbf{n}=\mathbf{2 2})$ & Non-breastfeeding $(\mathbf{n}=\mathbf{1 0})$ & $\mathbf{p}$ \\
\hline HbA1c $(\%)$ & $6.1 \pm 0.6$ & $6.2 \pm 1.0$ & NS \\
Adherence to the recommendations (\%) & $60.2 \pm 24.5$ & $91.4 \pm 38.9$ & 0.01 \\
Amount of carbohydrates intake/day [g] & $148.2 \pm 55.9$ & $175.2 \pm 64.0$ & NS \\
\hline
\end{tabular}

NS - non-significant

Table 5. Breakdown of body mass index (BMI) among women breastfeeding and non-breastfeeding postpartum

\begin{tabular}{lccc}
\hline & Breastfeeding $(\mathbf{n}=\mathbf{2 2})$ & Non-breastfeeding $(\mathbf{n}=\mathbf{1 0})$ & $\mathbf{p}$ \\
\hline $\mathrm{BMI}-1^{\text {st }}$ trimester $\left[\mathrm{kg} / \mathrm{m}^{2}\right]$ & $22.6 \pm 2.9$ & $22.2 \pm 3.5$ & $\mathrm{NS}$ \\
$\mathrm{BMI}-2^{\text {nd }}$ trimester $\left[\mathrm{kg} / \mathrm{m}^{2}\right]$ & $25.2 \pm 3.3$ & $25.0 \pm 4.0$ & NS \\
$\mathrm{BMI}-3^{\text {rd }}$ trimester $\left[\mathrm{kg} / \mathrm{m}^{2}\right]$ & $26.7 \pm 3.8$ & $27.3 \pm 3.8$ & NS \\
$\mathrm{BMI}-$ after the delivery $\left[\mathrm{kg} / \mathrm{m}^{2}\right]$ & $23.5 \pm 3.3$ & $24.9 \pm 3.7$ & NS \\
\hline
\end{tabular}

NS - non-significant

after birth for breastfeeding and non-breastfeeding women are presented in Table 4.

The recommended daily carbohydrate intake calculated according to the guidelines of the Polish Gynaecological Society and the Diabetes Poland for the entire study group was approx. $205.6 \pm 34.2 \mathrm{~g}$ of carbohydrates. For patients with normal body weight at the moment of pregnancy diagnosis, the calculated average recommended carbohydrate intake was at the level of 221.2 \pm 22.8 per day, while for the patients with diagnosed overweight at the moment of pregnancy diagnosis $159.1 \pm 13.5 \mathrm{~g}$. The difference in the recommended daily carbohydrate intake for both groups resulted from reduction of caloric intake for overweight patients in order to normalize their body weight and reduce risk of its excessive increase during pregnancy.

The carbohydrate intake by pregnant patients and adherence to the recommendations in each trimester and after birth is presented in Table 3. We observed a statistically significant decrease in the adherence to the carbohydrate intake recommendations after pregnancy. A statistically significant difference in the adherence to the recommended carbohydrate intake among breastfeeding and non-breastfeeding women is shown in Table 4. The breastfeeding patients consumed on average as much as $101.2 \pm 63.0 \mathrm{~g}$ of carbohydrates which is less than recommended intake, while non-breastfeeding women consumed only 26.2 $\pm 80.8 \mathrm{~g}$ of carbohydrates less than recommended intake. However, there were no statistically significant difference in distribution of body weight in breastfeeding and non-breastfeeding patients (Table 5) that could indicate reduction of consumed carbohydrates in breast-feeding women because because of quick return to pre-pregnancy weight.

The average body weight increase during pregnancy in the study group was $12.4 \pm 5.7 \mathrm{~kg}$. The average birth weight was $3641 \pm 481 \mathrm{~g}$.

Moreover, the study involved the following of the recommended carbohydrate intake depending on $\mathrm{BMI}$ at the moment of pregnancy diagnosis (Table 6). A statistically significant difference was found in the adherence to the recommendations in the $1^{\text {st }}$ and $2^{\text {nd }}$ trimester between patients of BMI $<25 \mathrm{~kg} / \mathrm{m}^{2}$ and patients of $B M I \geq 25 \mathrm{~kg} / \mathrm{m}^{2}$. In the first trimester, patients with normal BMI consumed on average $59.8 \pm$ 
Table 6. Comparison of intake of carbohydrates, the adherence to the recommendations, and daily insulin requirement depending on body mass index BMI in the $1^{\text {st }}$ and $2^{\text {nd }}$ trimester

\begin{tabular}{|c|c|c|c|c|c|c|}
\hline & \multicolumn{3}{|c|}{$1^{\text {st }}$ trimester } & \multicolumn{3}{|c|}{$2^{\text {nd }}$ trimester } \\
\hline & $\begin{array}{c}\text { BMI < } 25 \\
(n=24)\end{array}$ & $\begin{array}{c}\text { BMI } \geq 25 \\
(n=8)\end{array}$ & $\mathbf{p}$ & $\begin{array}{c}\text { BMI < } 25 \\
(n=24)\end{array}$ & $\begin{array}{c}\text { BMI } \geq 25 \\
(n=8)\end{array}$ & $\mathbf{p}$ \\
\hline Amount of carbohydrates intake/day [g] & $161.4 \pm 42.1$ & $174.7 \pm 48.0$ & NS & $184.6 \pm 54.8$ & $179.7 \pm 49.0$ & NS \\
\hline Adherence to the recommendations (\%) & $73.4 \pm 19.9$ & $111.0 \pm 32.1$ & 0.007 & $83.4 \pm 23.7$ & $114.5 \pm 34.9$ & 0.02 \\
\hline Insulin quantity/day [u] & $33.1 \pm 7.3$ & $43.8 \pm 7.4$ & 0.003 & $42.1 \pm 10.6$ & $50.8 \pm 9.9$ & 0.02 \\
\hline
\end{tabular}

NS - non-significant

Table 7. Comparison of intake of carbohydrates, adherence to the recommendations, and daily insulin requirement depending on body mass index (BMI) in the $3^{\text {rd }}$ trimester and 8 weeks after birth

\begin{tabular}{|c|c|c|c|c|c|c|}
\hline & \multicolumn{3}{|c|}{$3^{\text {rd }}$ trimester } & \multicolumn{3}{|c|}{8 weeks after birth } \\
\hline & $\begin{array}{c}\text { BMI < } 25 \\
(n=24)\end{array}$ & $\begin{array}{c}\text { BMI } \geq 25 \\
(n=8)\end{array}$ & p & $\begin{array}{c}\text { BMI < } 25 \\
(n=24)\end{array}$ & $\begin{array}{c}\text { BMI } \geq 25 \\
(n=8)\end{array}$ & p \\
\hline Carbohydrates intake/day [g] & $201.5 \pm 68.7$ & $181.7 \pm 62.3$ & NS & $155.9 \pm 57.3$ & $158.7 \pm 67.5$ & NS \\
\hline Adherence to the recommendations (\%) & $91.2 \pm 30.2$ & $115.8 \pm 42.9$ & NS & $63.4 \pm 25.3$ & $89.8 \pm 44.7$ & 0.04 \\
\hline Insulin quantity/day [u] & $62.7 \pm 21.5$ & $72.7 \pm 11.6$ & NS & $32.5 \pm 11.3$ & $35.0 \pm 7.7$ & NS \\
\hline
\end{tabular}

NS - non-significant

$\pm 44.9 \mathrm{~g}$ of carbohydrates less than recommended intake, while overweight patients consumed on average $15.7 \pm 52.7 \mathrm{~g}$ of carbohydrates more than recommended intake. This difference was statistically significant. In the $2^{\text {nd }}$ trimester, women with normal BMI consumed on average $36.5 \pm 51.1 \mathrm{~g}$ of carbohydrates less than recommended intake, while overweight patients exceeded recommended intake on average by $20.1 \pm 54.9 \mathrm{~g}(\mathrm{p}=0.02)$.

Similar trend, in spite of lack of statistical significance, was maintained in the $3^{\text {rd }}$ trimester (Table 7), when women with BMI below $25 \mathrm{~kg} / \mathrm{m}^{2}$ consumed on average $19.6 \pm 66.7 \mathrm{~g}$ of carbohydrates less than recommended intake, while women with BMI above $25 \mathrm{~kg} / \mathrm{m}^{2}$ exceeded the recommended value by $22.6 \pm 67.5 \mathrm{~g}$.

After delivery, both groups, those with initially normal body weight as well as overweight ones did not achieve $100 \%$ of recommended carbohydrate intake (Table 7). However, the statistically significant difference was found in the adherence to the dietary recommendations regarding carbohydrate intake in women with $\mathrm{BMI}<25 \mathrm{~kg} / \mathrm{m}^{2}$ and $\mathrm{BMI} \geq 25 \mathrm{~kg} / \mathrm{m}^{2}$ after delivery (Table 7). After delivery, subjects with BMI below $25 \mathrm{~kg} / \mathrm{m}^{2}$ consumed on average $96.1 \pm 68.1 \mathrm{~g}$ of carbohydrates less than recommended intake, while overweight patients consumed only $24.2 \pm 79.1 \mathrm{~g}$ of carbohydrates less than recommended intake.

Among women with initial BMI below $25 \mathrm{~kg} / \mathrm{m}^{2}$ average increase in body weight was $12.2 \pm 4.0$, whereas for women with BMI equal to $25 \mathrm{~kg} / \mathrm{m}^{2}$ or higher, average increase in body weight was $12.8 \pm$ $\pm 9.5 \mathrm{~kg}$. This difference was not statistically significant.

In the analysed group, there was no statistically significant $(p=0.827)$ difference in birth weights as a function of mother body weight: among women of normal BMI at the beginning of the pregnancy, average birth weight was $3625 \pm 522 \mathrm{~g}$, while in subjects overweight at the moment of pregnancy diagnosis $-3690 \pm 354 \mathrm{~g}$.

\section{Discussion}

Numerous scientific reports indicate a great importance of proper dietary intervention regarding the therapy of type 1 diabetic women during pregnancy. Appropriate intake of essential nutrients is the basis for optimum obstetric results. Both quality of consumed nutrients, and their quantity are important factors determining correct development and growth of the foetus. In PGDM, dietary intervention should be selected in such a manner to obtain optimal metabolism control of diabetes [11, 12]. Carbohydrates are main nutrient having direct effect on glucose blood concentration. The appropriate type of consumed carbohydrates, as well as their quantity and breakdown per individual meals are important. This study assess daily carbohydrate intake in relation to recommended intake in the individual trimesters and after delivery.

The assessment of carbohydrate intake was based on data from the CSII. In order to increase accuracy of 
obtained results, the subjects were asked to keep self-control diary and recording quantities of consumed CE. However, it must be noted that both methods in certain cases may be inaccurate and imprecise. The results depend on the reliability of keeping selfmonitoring by a patient, possible underestimation of consumed carbohydrates, omitting boluses or using manual boluses. This may be especially true for patients after the delivery due to new responsibilities and lack of time. Therefore, in order to improve accuracy of the obtained data, it was decided to use additional dietary diary which supplements CSII data.

The literature provides very small number of studies assessing carbohydrate content in daily food rations in type 1 diabetic women during pregnancy and after the delivery. The majority of analyses focus on gestational diabetes and not PGDM. In the years 2008-2010 Lim SY et al. have conducted studies assessing intake of nutrients in the study group of 111 subjects with gestational diabetes, with no prior dietary training. They observed that diet of women with GDM was unbalanced in consumption of macro- and micronutrients. The carbohydrate content in daily food rations of the subjects was at the average level of $224 \mathrm{~g}$ [13]. It was shown that carbohydrate intake was approx. 252.3 $g$ per day, which accounts for $54 \%$ of GDA in 94 female subjects with gestational diabetes in the United Arab Emirates [11]. Similar results were obtained by Savith et al. in the study group of 120 subjects with gestational diabetes and pre-gestational diabetes in Chennai, India. In this study, women with gestational diabetes consumed on average $348 \mathrm{~g}$ of carbohydrates, which accounted for approx. 59\% of daily energy requirements, while subjects with PGDM consumed on average of $298 \mathrm{~g}$ of carbohydrates, which allowed to achieve carbohydrate intake at level of approx. $55 \%$ of GDA [14]. In this study carbohydrate intake in women with PDGM did not reach recommended value of 205 $\mathrm{g}$ in any trimester. This would account for approx. $40-45 \%$ of GDA. The patients were taught and monitored regarding dietary and correct weight increase on each medical examination (every 2 weeks) and once a trimester they underwent special dietary trainings. In this study subjects consumed less carbohydrates than recommended. However, the analysis of subgroup of subjects with initial BMI above $25 \mathrm{~kg} / \mathrm{m}^{2}$ indicates a large exceedance of recommended daily carbohydrate intake, despite the dietary training.

The results of the study by Chalcarz et al. conducted on a group of 10 women with gestational diabetes in a third trimester, were similar to ones obtained in this research. The average daily intake of carbohydrates was at the level of $200.6 \mathrm{~g}$ [15]. Such a big difference between results of individual studies are caused by difference in the diet due to cultural distinctiveness of given countries, various models of health care and incomparable availability of dietary education. It is also hard to compare results for subjects with PDGM to subjects with gestational diabetes.

Ghani et al. involved group of 77 women and proved that diet containing approx. 221 of carbohydrates of low glycemic index daily has positive effect on the fasting blood glucose level in women after gestational diabetes [16]. Chun Yu Louie et al. proved that women with gestational diabetes do not have an appropriate diet, which is related mainly to intake and quality of consumed carbohydrates. The study conducted in Australia and involved the study group of 82 female subjects with gestational diabetes, who after the group dietary education, were requested to complete 3-day report on consumption of food products and meals in order to evaluate their daily dietary composition. Average carbohydrate content in this study group was $166 \pm 5 \mathrm{~g}$ per day. The study showed that lower glycemic load and index of consumed products results in diet containing more nutrients. Low consumption of products containing carbohydrates in the group caused decrease in diet of the following nutrients: fiber, magnesium, iron, folic acid, potassium, and increasing content of saturated fatty acids and sodium resulting from consumption of products rich in these nutrients [17]. In this study, there was no detailed analysis of menu regarding other nutrients, but one may assume that low intake of carbohydrates in the analysed group may contribute to diet lower in minerals and vitamins that originate from carbohydrates. Some studies show that women with gestational diabetes deliberately avoid foods rich in carbohydrates such as fruits, or cereal products in order to avoid insulin treatment [18]. In case of women with pre-gestational diabetes there should be no such problems, as they are already treated with insulin. The studies conducted in the United Kingdom and Spain confirm low consumption of nutrients by women with gestational diabetes $[19,20]$.

In this study, low carbohydrate intake was observed, especially in the first trimester. The current studies show that nausea and vomiting complicating the pregnancy may have negative effect on quantitative and nutritional composition of diet in pregnant women [21, 22]. Such problems occur at the early stage of the pregnancy and may lead to decrease the amount of nutrients in pregnant women's diet. However, it is certain that restrictions in carbohydrate intake in the initial weeks of the pregnancy may be a result of higher motivation of patients to better control diabetes metabolism by omitting nutrients affecting 
glycemic values. At the beginning of the pregnancy, our patients were intensively educated with special attention to the role of carbohydrates in the normal pregnancy. In the $2^{\text {nd }}$ and $3^{\text {rd }}$ trimester, an increase in carbohydrate intake was observed, approaching the recommended value, which may be both result of the regression of nausea and vomiting, better motivation of subjects, as well as of intensive dietary education. Despite increased carbohydrate intake in the $2^{\text {nd }}$ and $3^{\text {rd }}$ trimester in comparison to the beginning of the pregnancy, an improvement of metabolic diabetes control was observed involving obtaining $\mathrm{HbA}_{1 \mathrm{c}}$ value below $6.0 \%$ recommended by the Diabetes Poland. The good health care results in normal birth weight after the pregnancy. Mother's hyperglycemia stimulates foetal insulin secretion through the placenta, which works as growth factor by contributing to increasing risk of foetal macrosomia [23]. The current data shows benefits of the diet with individually calculated carbohydrate content on control of blood glucose concentration, which in combination with daily monitoring of dietary energy intake and appropriate insulin therapy can decrease risk of foetal macrosomia [24]. This is confirmed by the results of this study, where dose of consumed carbohydrates was calculated individually for each patient.

The observation following the end of pregnancy is also interesting. After the delivery all the patients consumed much less carbohydrates than recommended intake. This was especially pronounced in breastfeeding women group, who consumed only $60 \%$ of recommended carbohydrate intake. According to the American Academy of Pediatrics, breastfeeding is related to increased energy and nutrient intake due to the increased basic metabolism relating to the milk production [10]. Despite increased demand, women do not increase quantity of consumed food, which was proven in the study by Zdanowski et al. involving group of 100 breastfeeding women, where recommendations regarding amount of consumed carbohydrates were followed only by $36 \%$ of group, while $64 \%$ had too low carbohydrate intake [25]. Many women during breastfeeding reduce consumption of certain foods that could have potential effect on risk of colic, skin lesions and allergies in infants, thus decreasing intake of energy and nutrients in diet. The Polish Expert Group for dietary recommendations for lactating women, after analysis of the available research, confirms that mother's diet during breastfeeding has no effect on risk of allergy in infants. It is also not recommended for breastfeeding mothers to have lactose-free and milk-free diet in case of baby colic. Dietary restrictions of mothers can be applied for reasonable suspicion of allergy to cow's milk protein in a child [26]. In some women, reduction of calories in diet is observed which could be caused by a desire to fast return to the pre-pregnancy weight. This may have a negative impact on quantity of produced milk [27]. In the study by Olejniczak and Krakowiak assessing needs of health education for pregnant women regarding life-style and breastfeeding, over $92.5 \%$ of women expressed the need for dietary education during lactation [28]. In this study, it was observed that non-breastfeeding patients followed the recommended carbohydrate intake in $90 \%$, i.e. much better than breastfeeding mothers. Reduction of carbohydrate intake among breastfeeding women could have been also related to adherence to the paediatric recommendations and elimination of potentially allergenic foods to the new born child or a desire to prompt return to the pre-pregnancy weight. In this own study, there was no differences found in body weight distribution after the delivery in both groups, i.e. breastfeeding and non-breastfeeding mothers. The reason for restricting carbohydrate consumption in breastfeeding patient group requires further observation.

Abundant scientific data shows that overweight or obese people have tendency to eat more food in comparison to people with normal body weight. Similar tendency was observed in this study. According to the recommendation of the Diabetes Poland and Polish Gynaecological Society in case of overweight or obesity during pregnancy, it is recommended to use reduction diet tailored to individual body needs in order to normalize body weight or to prevent its excessive increase during pregnancy. Despite these recommendation, results of our own study indicates that women with BMI over $25 \mathrm{~kg} / \mathrm{m}^{2}$ consumed much more carbohydrates in relation to recommended intake than women with normal body weight. A statistically significant difference was found in recommended carbohydrate intake between both groups in the $1^{\text {st }}$ and $2^{\text {nd }}$ trimester and after birth. Despite the same dietary education in the entire study group through the entire pregnancy, patients with BMl above $25 \mathrm{~kg} / \mathrm{m}^{2}$ presented worse adherence to the recommendation by exceeding calculated carbohydrate intake to much extent.

The type 1 diabetic pregnant patient group presented in this study was strongly motivated and underwent intensive dietary education. The study did not involve observation of patients without prior dietary education. Numerous scientific reports discuss issue of gestational diabetes, but not all the observations can be related directly to pre-gestational diabetes mellitus. Diet and nutrient content in the daily food rations in subjects with PDGM requires further observation. 


\section{Conclusions}

1. Pregnant women with normal body weight before pregnancy consumed less carbohydrates than recommended.

2. Adherence to the dietary recommendations significantly differed in particular trimesters and 8 weeks after the delivery.

3. We observed decrease in the adherence to recommendations after the delivery.

4. Breastfeeding women consumed less carbohydrates than non-breastfeeding.

5. Overweight women consumed more carbohydrates than recommended.

\section{Conflict of interest}

The above-mentioned authors declare that they have no conflicts of interest in connection with the published work.

\section{REFERENCES}

1. Cukrzyca a ciąża. Zalecenia kliniczne dotyczące postępowania u chorych na cukrzycę 2014. Stanowisko Polskiego Towarzystwa Diabetologicznego. Diabet Klin 2014; 3 (Suppl A): 46-49.

2. Grzelak T, Janicka E, Kramkowska M et al. Cukrzyca ciążowa skutki niewyrównania i podstawy regulacji glikemii. Nowiny Lek 2013; 82: 163-169.

3. Standardy Polskiego Towarzystwa Ginekologicznego postępowania u kobiet z cukrzycą. Ginekol Pol 2014; 85: 476-478.

4. Franz MJ, Bantle JP, Beebe CA et al. Evidence-based nutrition principles and recommendations for the treatment and prevention of diabetes and related complications. Diabetes Care 2002; 25: 148-198.

5. Wójcikowski C, Wender-Ożegowska E, Cypryk K. Cukrzyca i ciąża. In: Sieracki J (ed.) Cukrzyca. Vol. II. Via Medica, Gdańsk 2006: 541-576.

6. American Diabetes Association. Foundations of care: education, nutrition, physical activity, smoking cessation, psychosocial care, and immunization. Standards of Medical Care in Diabetes 2015. Diabetes Care 2015; 38 (Suppl 1): S20-S30.

7. Roskjaer $A B$, Andersen JR, Ronneby $\mathrm{H}$ et al. Dietary advices on carbohydrate intake for pregnant women with type 1 diabetes. J Matern Fetal Neonatal Med 2015; 28: 229-233.

8. Hernendez TL, Van Pelt RE, Anderson MA et al. A higher-complex carbohydrate diet in gestational diabetes mellitus achieves glucose targets and lowers postprandial lipids: a randomized crossover study. Diabetes Care 2014; 37: 1254-1262.
9. Morisset AS, Cote JA, Michaud A et al. Dietary intake in the nutritional management of gestational diabetes mellitus. Can J Diet Pract Res 2014; 75: 64-71

10. American Academy of Pediatrics. Breastfeeding and the use of human milk. Pediatrics 2012; 129: 827-841.

11. Ali $H I$, Jarrar $A H$, Sadig $M$ et al. Diet an carbohydrate food knowledge of multi-ethnic women: A comparative analysis of pregnant women with and without gestational diabetes mellitus. PLoS ONE 2013; 8: 1-9.

12. Magon N, Seshiah V. Gestational diabetes mellitus: non-insulin management. Indian J Endocrinol Metab 2011; 15: 284-293.

13. Lim SY, Yoo HJ, Kim AL et al. Nutritional intake of pregnant women with gestational diabetes or type 2 diabetes mellitus, Clin Nutr Res 2013; 2: 81-90.

14. Savitha P, Mageshwari SU. Nutritional adequacy of gestational diabetes and pre-gestational diabetes women. Inter J Medical Science and Public Health 2013; 2: 598-602.

15. Chalcarz W, Merkiel S, Wandelt K. Assessment of dietary intake in women with gestational diabetes mellitus. Preliminary report. Nowa Med 2007; 2: 27-30.

16. Ghani RA, Shyam S, Arshad F et al. The influence of fasting insulin level in post-gestational diabetes mellitus women receiving low-glycaemic-index diets. Nutr Diab 2014; 4: 1-5.

17. Chun Yo Louie J, Markovic TP, Ross GP et al. Higher glycemic load diet is associated with poorer nutrient intake in women with gestational diabetes mellitus. Nutr Res 2013; 33: 259-265.

18. Evert $A B$, Hei KV. Gestational diabetes education and diabetes prevention strategies. Diab Spectr 2006; 19: 135-139.

19. Thomas B, Ghebremeskel K, Lowy C et al. Nutrient intake of women with and without gestational diabetes with a specific focus on fatty acids. Nutrition 2006; 22: 230-236.

20. Gonzalez-Clemente JM, Carro O, Gallach I et al. Increased cholesterol intake in women with gestational diabetes mellitus. Diabetes Metab 2007; 33: 25-29.

21. Winkvist A, Persson V, Hartini TN. Underreporting of energy intake is less common among pregnant women in Indonesia. Public Health Nutr 2002; 5: 523-529.

22. Latva-Pukkila $U$, Isolauri $E$, Laitinen $K$. Dietary and clinical impacts of nausea and vomiting during pregnancy. J Hum Nutr Diet 2010; 23: 69-77.

23. Petry CJ. Gestational diabetes: risk factors and recent advances in its genetics and treatment. Br J Nutr 2010; 104: 775-787.

24. Carroll MA, Yeomans ER. Diabetic ketoacidosis in pregnancy. Crit Care Med 2005; 33: 347-353.

25. Zdanowski K, Wawrzyniak A, Hamułka J et al. Ocena spożycia energii oraz składników podstawowych w grupie kobiet karmiących piersią. Rocz Państ Zakł Hig 2012; 63: 305-311.

26. Borszewska-Kormacka M, Rachtan-Janicka J, Wesołowska A et al. Stanowisko grupy ekspertów w sprawie zaleceń żywieniowych dla kobiet w okresie laktacji. Stand Med Pediatr 2013; 10: 265-279.

27. Ministry of Health. Food and Nutrition Guidelines for Healthy Pregnant and Breastfeeding Women: A background paper. Ministry of Health, Wellington 2006.

28. Olejniczak D, Krakowiak K. Ocena potrzeby edukacji zdrowotnej kobiet w ciąży w zakresie stylu życia i karmienia piersią. Nowa Ped 2013; 3: 97-105. 